\title{
PENYULUHAN TENTANG PERLINDUNGAN HUKUM INDIKASI GEOGRAFIS BERAS PANDANWANGI CIANJUR JAWA BARAT SEBAGAI WUJUD SUMBANGSIH UNISBA DALAM MENINGKATKAN INDEKS PEMBANGUNAN MANUSIA (IPM)
}

\author{
Tatty A. Ramli, dan Yety Sumiyati. \\ Dosen Fakultas Hukum Universitas Islam Bandung \\ E-mail: yeti_sumiyati@yahoo.com
}

\section{PENDAHULUAN}

Kata pandan wangi adalah petunjuk untuk suatu jenis benih padi yang mempunyai ciri-ciri tertentu seperti: 1) butiran gabahnya yang kuning keemasan; 2) tangkainya yang tumbuh lebih tinggi dari padi jenis lain; 3) daunnya yang merunduk hingga 45 derajat; dan 4) butiran berasnya sendiri memiliki inti yang biasa disebut telur dan, jika diterawang, urat-urat pada bulirnya terlihat jelas. (lihat SK Menteri Pertanian No. 103). Aroma pandannya yang khas bertahan cukup lama dan semakin tercium setelah dicuci. Setelah dimasak, kepulenan beras Pandan Wangi tetap bertahan meski nasinya sudah dingin karena kandungan amilosanya yang mencapai 26 persen.

Tidak semua lahan di wilayah Kab. Cianjur berkarakter seperti itu. Tanah andosol/regina hanya terdapat di Kec. Warungkondang, Kec. Cugenang, Kec. Cibeber, Kec. Cianjur, dan Kec. Cilaku. Itulah mengapa Pandan Wangi dengan kualitas terbaik hanya bisa diperoleh di lima kecamatan itu. Jika ditanam di luar wilayah itu, rasa Pandan Wangi akan berbeda dan aromanya tidak muncul, apalagi kalau ditanam di luar Cianjur. (Handri Handrian, 2009)

Umumnya kata pandan wangi selalu diikuti oleh kata "Cianjur" karena diasosiasikan sebagai beras yang berasal dari cianjur dan identik dengan kualitas dan kharakter beras yang mempunyai keunggulan dibandingkan dengan beras beras produksi wilayahwilayah lain Indonesia. Keunggulan dalam kualitas dan karakter ini timbul karena ada pengaruh dari faktor lingkungan dan juga faktor manusia ketika proses penanaman, pemanenan dan penyimpanan beras Pandan Wangi. Karena kualitas nya yang unggul tersebut maka harga jual dari beras Pandan Wangi "Cianjur" jauh lebih mahal daripada harga beras pada umumnya.

Pada beberapa tahun terakhir beberapa pihak seperti tim peneliti IPB, (www.indosiar.com) asosiasi pedagang beras pandan wangi, asosiasi petani beras pandan wangi, dinas pertanian dan pemerintah Cianjur juga dari beberapa keluhan konsumen, ditenggarai telah terjadi pemalsuan terhadap beras Pandan Wangi "Cianjur". Pemalsuan tersebut melalui beberapa modus, beras yang bukan berasal dari benih pandan wangi asli dioplos beras pandanwangi asli, beras bukan pandan wangi diberi essence pewangi serupa pandan wangi dengan bahan kimia, atau dengan menjual beras pandan wangi dalam kemasan yang labelnya mencantumkan kata "Cianjur". (Handri Handrian, 2009)

Benih beras pandan wangi memang dapat tumbuh di sembarang tempat, namun diketahui bahwa apabila benih beras pandan wangi ditanam di areal-areal tertentu di Cianjur seperti di wilayah Kec. Warungkondang, Kec. Cugenang, Kec. Cibeber, Kec. Cianjur, dan Kec. Cilaku hasil panen nya berbeda Karen kualitas dan karakter nya tidak sama. Perbedaan nya terletak pada ukuran bulir beras, tanda putih pada bulir dan yang sangat popular adalah aromanya. Atas perbuatan pemalsuan beras Pandan Wangi "Cianjur" tersebut di atas yang berpotensi merugikan, belum ada tindakan hukum atau upaya hukum yang tepat dan memadai dari pihak terkait beras Pandan Wangi "Cianjur". Pada akhirnya tindakan pemalsuan beras Pandan Wangi "Cianjur" merugikan petani, produsen, dan konsumen beras.

H. Pepen Jaenudin, Sekretaris Gapoktan Citra Sawargi, Kab. Cianjur menjelaskan bahwa sampai saat ini para pelaku pemalsuan beras Pandan Wangi dapat dengan bebas menjalankan aksinya di pasar tanpa hukuman atau sanksi. Praktek penggunaan essence oleh produsen tidak bertanggung jawab terhadap beras varietas lain agar seolah-olah beras tersebut adalah beras Pandan Wangi Cianjur menambah luasnya praktek penjualan beras Pandan Wangi palsu. Lemahnya pengawasan dan ketiadaan sanksi atas tindakan tersebut membuat konsumen kesulitan membedakan keaslian beras Pandan Wangi Cianjur.

Menurut keterangan Kepala Bidang Tanaman Pangan pada Dinas Pertanian Kab. Cianjur Henny Iriani, padi jenis tersebut hanya bisa ditanam di daerah dengan ketinggian 500 (lima ratus) hingga 800 (delapan ratus) meter di atas permukaan laut dan bersuhu 20-27 derajat Celsius. Kelebihan karakteristik daerah asal Pandan Wangi adalah jenis tanah yang berupa tanah andosol/regina. Memang secara spesifik ilmiah, belum ada penelitian yang mempelajari kandungan dan struktur tanah jenis ini. Namun, di dunia, tanah sejenis ini hanya ditemukan di Brasil dan di beberapa daerah Kabupaten Cianjur.

Sekarang, deskripsi padi sawah varietas pandan wangi secara jelas telah dituangkan dalam Keputusan Menteri Pertanian Nomor 163/Kpts/ LB.240/ 3/ 2004 tentang Pelepasan Galur Padi Sawah Lokal Pandan Wangi Cianjur sebagai Varietas Unggul dengan Nama "Pandan Wangi". Secara teknis, beras Pandan Wangi termasuk varietas Javonica alias padi bulu.

Berbagai upaya penyelamatan terus dilakukan oleh Gapoktan Citra Sawargi Kab. Cianjur. Akan tetapi meluasnya penjualan beras berlabel Pandan Wangi Cianjur tetap tidak dapat dikendalikan. Pepen berharap, Pemkab Cianjur segera melangkah untuk melindungi para petani dengan cara membuat hak paten. Hasil produksi petani dibeli pemkab dan dipasarkan dengan merek dagang yang sudah diberi hak paten tersebut.

Keresahan petani, dari sudut pandang akademisi harus diluruskan duduk persoalannya. Ibu Yeti Sumiyati, SH.,MH. menulis artikel di Harian Umum Pikiran Rakyat, tepatnya pada Rabu, 17 Juni 2009. Artikel tersebut berusaha untuk menjelaskan bahwa beras Pandan Wangi Cianjur berpotensi untuk dilindungi dengan Perlindungan Hukum Indikasi Geografis, bukan melalui paten, karena hak paten adalah perlindungan hukum untuk penemuan baru di bidang teknologi yang sama sekali tidak ada dalam produk beras. 
Dari perspektif hukum Hak Kekayaan Intelektual, nama suatu wilayah yang mana dari wilayah tersebut dihasilkan suatu produk alam atau kerajinan yang mempunyai karakter dan kualitas berbeda dengan produk sejenis dan hal itu diakibatkan karena adanya pengaruh dari faktor alam/geografis atau faktor manusia atau keduanya, maka nama wilayah itu dilindungi. Perlindungan untuk nama wilayah tersebut dikenal dengan "Hak Indikasi Geografis" yang di atur dalam UU merek No. 15 tahun 2000 tentang Merek dan Peraturan Pemerintah No. 51 tahun 2007 tentang Indikasi Geografis.

Indikasi Geografis adalah suatu ekspresi yang menghubungkan asal produk dengan wilayah geografis tertentu yang dapat menjadi dasar bagi klain suatu hak. Dengan kata lain, pengertian seperti itu menunjukan bahwa produk-produk yang bersangkutan berasal dari wilayah tersebut. Oleh karena itu, Indikasi Geografis adalah suatu terminologi yang luas yang menunjuk pada jenis ekspresi yang dapat diasosiasikan sebagai asal geografis suatu produk. (Suyud Margono, 2002) Indikasi Geografis memberikan perlindungan terhadap tanda yang mengidentifikasikan suatu wilayah negara, atau kawasan atau daerah di dalam wilayah tersebut sebagai asal barang, dimana reputasi, kualitas dan karakteristik barang tersebut sangat ditentukan oleh factor geografis yang bersangkutan. (Sommeng dan Sasongko. 2008)

Menurut Pasal 1 angka 1 Peraturan Pemerintah Nomor 51 Tahun 2007 tentang Indikasi Geografis, Indikasi Geografis adalah suatu tanda yang menunjukkan daerah asal suatu barang, yang karena faktor lingkungan geografis termasuk faktor alam, faktor manusia, atau kombinasi dari kedua faktor tersebut, memberikan ciri dan kualitas tertentu pada barang yang dihasilkan.

Pelaku pelanggaran atas Hak Indikasi Geografis diancam hukuman. Untuk dapat mengajukan gugatan kepada pihak yang melakukan pelanggaran, hal pertama yang harus dibuktikan adalah apakah nama wilayah yang penggunaannya dilanggar tersebut sudah terdaftar sebagai indikasi geografis yang dilindungi atau belum. Direktorat Jenderal HKI di bawah Departemen Hukum dan HAM merupakan lembaga yang mengadminstrasikan perlindungan HKI dapat dirujuk untuk hal tersebut melalui catatan registrasi pendaftarann Indikasi Geografis. Sertifikat Indikasi geografis adalah bukti formal dari perlindungan hukum yang sah bagi sebuah Indikasi Geografis.

Berdasarkan uraian-uraian di atas, muncul gagasan untuk melakukan Pengabdian Kepada Masyarakat (PKM) sebagai wujud sumbangsih Unisba untuk ikut berkontribusi terhadap terciptanya peningkatan SDM yang akan mendukung pertumbuhan ekonomi masyarakat yang melalui penyuluhan tentang perlindungan hukum Indikasi Geografis Beras Pandan Wangi Cianjur Jawa Barat sebagai wujud sumbangsih UNISBA Dalam Meningkatkan Indeks Pembangunan Manusia (IPM), Kec. Warungkondang, Kec. Cugenang, Kec. Cibeber, Kec. Cianjur, dan Kec. Cilaku Kab. Cianjur ini dipilih sebagai khalayak sasaran strategis dengan pertimbangan bahwa:

1. Wilayah tersebut produknya mempunyai potensi untuk mendapat perlindungan hukum Indikasi Geografis karena memiliki karakteristik dan ciri khas tersendiri sebagai akibat dari faktor geografis.

2. Masyarakat sangat membutuhkan pengetahuan dan pemahaman mengenai perlindungan hukum terhadap hasil alamnya yaitu beras Pandan Wangi Cianjur yang selama ini banyak dipalsukan.

Metode penyuluhan hukum perlindungan yang dijamah adalah metode langsung dan tidak langsung. Dalam metode penyuluhan hukum langsung, kegiatan penyuluhan hukum ini dilakukan secara langsung dengan cara berhadapan langsung dengan masyarakat masyarakat yang disuluh antara lain petani, pejabat/ aparatur daerah dan dinas terkait. Kegiatan yang dilakukan mencakup ceramah, dialog, sarasehan, dan diskusi. Metode penyuluhan tidak langsung dilakukan melalui media. Penyuluh melakukan publikasi melalui media koran pikiran rakyat pada tanggal 17 juni 2009 melalui artikel dengan topik "masih ada harapan bagi pandanwangi"

Berdasarkan uraian tersebut, Ada beberapa permasalahan yang dapat dijadikan kajian: 1) adanya ketidaktahuan masyarakat bahwa beras Pandan Wangi Cianjur perpotensi ekonomi apabila dilindungi dengan perlindungan Indikasi Geografis; 2) bahwa perlindungan Indikasi Geografis tidak dapat diperoleh secara otomatis melainkan harus melalui permohonan pendaftaran ke Dirjen HKI dengan persyaratanpersyaratan khusus sesuai dengan yang diatur dalam Peraturan Pemerintah Nomor 51 Taun 2007 tentang Indikasi Geografis.

\section{HASIL DAN PEMBAHASAN}

\section{A. Deskripsi Beras Pandan Wangi Cianjur}

Padi sawah Pandan Wangi mulai berkembang di Kabupaten Cianjur pada tahun 1970. Pada awal tahun tersebut seorang tengkulak gabah (Pak Kosim) memberikan benih padi kepada Bapak H. Nawawi (Alm.) seorang petani andalan dari Desa Mayak, Kecamatan Cibeber Cianjur.

Keberhasilan beliau dalam menanam varietas Pandan Wangi mendorong Bapak H. Dimyati dan bapak H Jalal (Alm.) untuk mengikuti jejaknya, dan masing-masing menanam varietas Pandan Wangi di daerah Jambu Dipa dan Bumikasih yang kedua-duanya ada di Kecamatan Warungkondang Kab. Cianjur.

Penyebaran Pandan Wangi dari tahun ke tahun mengalami peningkatan dan menyebar dari Kecamatan Warungkondang ke Kecamatan Cibeber, Cugenang, Cilaku, Cianjur, dan kecamatan lainnya di Kab. Cianjur. Namun penyebaran terbesar ada di 5 (lima) kecamatan tadi dan sampai sekarang menjadi sentra produksi padi Pandan Wangi.

Secara teknis, beras Pandan Wangi termasuk varietas Javonica alias padi bulu. Ciri khas tanaman padi Pandan Wangi adalah butiran gabahnya yang kuning keemasan, tangkainya yang tumbuh lebih tinggi dari padi jenis lain, dan daunnya yang merunduk hingga 45 derajat. Butiran berasnya sendiri memiliki inti yang biasa disebut telur dan, jika diterawang, urat-urat pada bulirnya terlihat jelas.

Selain itu, aroma pandannya yang khas bertahan cukup lama dan semakin tercium setelah dicuci. Setelah 
dimasak, kepulenan beras Pandan Wangi tetap bertahan meski nasinya sudah dingin. Hal ini disebabkan kandungan amilosanya yang mencapai 26 persen.

Padi jenis tersebut hanya bisa ditanam di daerah dengan ketinggian lima ratus hingga delapan ratus meter di atas permukaan laut dan bersuhu 2027 derajat Celsius. Adapun kelebihan karakteristik daerah asal Pandan Wangi adalah jenis tanah andosol/ regina. Secara spesifik ilmiah, memang, belum ada penelitian yang mempelajari kandungan dan struktur tanah jenis ini. Namun, di dunia, tanah jenis ini hanya dapat ditemukan di Brasil dan di beberapa daerah di Cianjur. Kendati demikian, tak semua lahan di wilayah Kab. Cianjur yang berkarakter seperti itu. Tanah andosol/regina hanya terdapat di Kec. Warungkondang, Kec. Cugenang, Kec. Cibeber, Kec. Cianjur, dan Kec. Cilaku. Itulah mengapa Pandan Wangi dengan kualitas terbaik hanya bisa diperoleh di lima kecamatan itu. Jika ditanam di luar wilayah itu, rasa Pandan Wangi akan berbeda dan aromanya tidak muncul, apalagi kalau ditanam di luar Cianjur.

\section{B. Upaya yang telah Dilakukan Aparat Pemda dan Masyarakat Kabupaten Cianjur}

Rencana PKM UNISBA disambut baik karena pihak Pemkab belum menemukan format yang tepat untuk melindungi beras Pandan Wangi Cianjur meskipun Pemkab telah menyadari bahwa beras Pandan Wangi Cianjur dapat menjadi asset yang potensial untuk mengembangkan perekonomian daerah. Selama ini telah dilakukan berbagai upaya untuk melindungi Beras Pandan Wangi Cianjur dari upaya-upaya pemalsuan, diantaranya dengan melakukan pemurnian dan standarisasi padi varietas Pandan Wangi.

Pemurnian dan standarisasi padi varietas Pandan Wangi dilatarbelakangi oleh banyaknya varietas lain yang menyerupai Beras Pandan Wangi Cianjur (aromatik), banyaknya persilangan yang dilakukan oleh petani sehingga mengakibatkan penurunan kualitas, munculnya varietas tersebut memungkinkan petani mempercepat masa panen menjadi 3 (tiga) kali dalam setahun, yang secara ekonomis lebih menguntungkan dibandingkan bila bertanam varietas Pandan Wangi yang hanya 1 kali dalam setahun.

Tujuan dilakukannya pemurnian dan standarisasi padi varietas Pandan Wangi adalah untuk memperoleh pengakuan nasional atas varietas padi sawah Pandan Wangi sebagai varietas lokal spesifik Kab. Cianjur, untuk mempertahankan keberadaan varietas Pandan Wangi secara lumintu (variety maintenance), mempertahankan ketersediaan benih sumber bermutu varietas Pandan Wangi secara berkesinambungan, dan menjajagi terbentuknya sistem usaha tani padi terintegrasi yang mengacu pada standarisasi mutu nasional. (berdasarkan wawancara dengan sdr. Henny)

Petani yang mendapatkan sertifikat untuk memperbanyak benih yang sudah dimurnikan adalah H. Mansur. H. Mansur adalah petani sekaligus ketua kelompok tani Karya Tirta sebagai salah satu kelompok tani di Desa Bunikasih Kec. Warungkondang Kab. Cianjur yang tergabung dalam Gapoktan Kab. Cianjur. Gapoktan Citra Sawargi juga telah melakukan berbagai upaya untuk mengembalikan kejayaan nama Pandan Wangi, termasuk upaya permurnian benih tersertifikasi yang dilakukan oleh H. Mansur. Setelah melakukan pemurnian benih dari beras oplosan yang sudah tercampur dengan varietas lain di pasar, sejak 1999, H. mansyur mendapat sertifikat benih Pandan Wangi murni dari Lembaga Penelitian dan Pemberdayaan Masyarakat (LPPM) IPB pada 2004. Petani sangat berharap ada upaya untuk melindungi penanaman dan pemasaran Beras Pandan Wangi Cianjur. Selama ini, karena ketiadaan perlindungan terhadap Beras Pandan Wangi Cianjur menyebabkan ghirah bertanam Pandan Wangi menurun drastis. Setiap tahun, luas tanam Pandan Wangi di Warungkondang, misalnya, terus menurun. Dari 2006 ke 2007 misalnya, luas tanam Pandan Wangi turun dari 450 hektare menjadi tiga ratus hektare. Jumlah itu kurang dari setengah dari total luas sawah di kecamatan itu. Luas sawah terus berkurang karena maraknya alih fungsi lahan. Sementara, luas tanam Pandan Wangi berkurang karena banyak petani yang beralih kepada varietas lain. Sebagaimana dijelaskan oleh H. Masur. Ketua Gapokan Citrasawargi.

Penyebab alih varietas yang dilakukan petani adalah pertimbangan waktu produksi varietas lain yang lebih cepat. Dengan perbedaan harga yang tidak terlalu jauh, petani jelas memilih mengembangkan varietas lain daripada Pandan Wangi. Saat ini, menurut Pepen, petani di Desa Jambudipa yang terkenal sebagai sentra produksi Pandan Wangi terbesar di era 1980-an, bahkan sudah seluruhnya beralih ke varietas lain. Mereka kini lebih memilih pindah ke varietas yang lebih cepat pertumbuhannya, seperti ciherang, intani, hibrida, sintanur, nekongga, dan sebagainya.

Upaya lain untuk melindungi Beras Pandan Wangi Cianjur adalah melalui pemantauan jalur pemasaran. Untuk pemasaran beras Pandan Wangi dari benih murni itu, Gapoktan Citra Sawargi kini menjalin kemitraan dengan CV Quasindo. Lewat perusahaan itu, beras Pandan Wangi murni asli dijual di pasar dalam kemasan lima kilogram dengan merek dagang Xiang Mie. Kendati demikian, usaha yang dilakukan saat ini masih belum bisa melindungi kesinambungan usaha petani Pandan Wangi Cianjur. Tetap saja masih banyak beras produksi daerah lain yang memakai label Pandan Wangi Cianjur. Ini jelas merugikan petani Cianjur, apalagi selama ini dinggap tidak ada payung hukum yang melindungi sehingga tidak dapat dilakukan penegakkan hukum atas pelanggaran-pelanggarannya.

\section{Pelaksanaan PKM sebagai Upaya Sosialisasi Perlindungan Hukum Indikasi Geografis Beras Pandan Wangi Cianjur}

Sebagaimanadiamanatkanolehpemerintahmelalui departemen pendidikan, pada hakekatnya pendidikan tinggi berfungsi mengembangkan kemampuan dan membentuk watak serta peradaban bangsa yang bermartabat dalam rangka mencerdaskan kehidupan bangsa dan melaksanakan tridharma yaitu, pendidikan, penelitian dan pengabdian kepada masyarakat. UNISBA sebagai salah satu Perguruan Tinggi Swasta Islam adalah bagian dari stakeholders Jawa Barat yang patut berpartisipasi aktif dan berkonstribusi positif melalui upaya upaya pengembangan sumber daya yang unggul dan produktif dalam kerangka pencapaian visi dan misi pembangunan Jawa Barat. Dosen UNISBA sebagai 
pendidik professional dan ilmuwan mempunyai tugas utama mentransformasikan, mengembangkan dan menyebarluaskan ilmu pengetahuan, tekhnologi juga seni melalui pengabdian kepada masyarakat.

Untuk mewujudkan Jawa Barat sebagai daerah yang mandiri, pemerintah daerah, warga masyarakat dan perguruan tinggi harus bersatu padu, bersinergi dan sabilulungan silih asah asih dan asuh dalam mengoptimalkan seluruh potensi daerah. Fakta yang menunjukkan bahwa kemampuan Sumber Daya Alam (SDA) daerah yang tidak terbaharukan semakin berkurang, sementara tuntutan pengembangan ekonomi berbasiskan ilmu pengetahuan dan ekonomi kreatif menjadi alternatif, menyebabkan perhatian kepada pembangunan ekonomi yang berbasis dan berkultur Hak Kekayaan Intelektual (HKI) tidak dapat ditampik lagi.

Pengabdian Kepada Masyarakat (PKM) UNISBA khususnya kepada pemangku kepentingan (stakeholders) Beras Pandan Wangi Cianjur adalah upaya membangun budaya hukum dengan cara mengedukasi penyelenggara negara, aparatur penegak hukum dan masyarakat pada umumnya bahwa nama wilayah "Cianjur" potensial untuk difungsikan sebagai "perekat " produk kepada daerah asal, sehingga produk yang dilindunginya dapat tetap memberikan keuntungan ekonomis tertinggi bagi produsen asli dari daerah asal produk tersebut.

Kegiatan PKM berupa penyuluhan hukum tentang Perlindungan Indikasi Geografis beras Pandan Wangi Cianjur ini, pada prinsipnya bermaksud untuk memantapkan penyemaian suatu konsep HKI ke lahan masyarakat agar terus berakar. Karena karakter kepemilikan Indikasi Geografis yang amat menghargai keterkaitan historis dari suatu produk dengan tempat asalnya, dan sifat kepemilikannya yang kolektif maka rezim HKI yang satu ini dibutuhkan oleh warga Cianjur untuk dapat "menguasai" produk-produk lokal/ daerah dan mencegah penyalahgunaannya oleh pihak lain

Pemangku kepentingan harus menyadari bahwa perlindungan HKI khususnya untuk perlindungan Indikasi Geografis atas nama "Cianjur" pada produk beras Pandan Wangi baru eksis setelah ada pengayoman/ penaungan atau perlindungan hukum dari Negara atau "otoritas" publik. Melalui hak yang didapat dari ototritas publik maka tumbuhlah eksklusifitas / kepemilikan yang bernilai ekonomi dan bersifat monopoli untuk jangka waktu tertentu dan syarat-syarat tertentu .

Penyuluhan tentang perlindungan hukum Indikasi Geografis Beras Pandan Wangi Cianjur dilaksanakan bertempat di rumah Bapak H. Mansur, Peserta yang hadir terdiri dari elemen Gabungan Kelompok Tani (Gapoktan) Cirtasawargi yang berada di lima wilayah antara lain Gapoktan Kec. Cugenang, Gapoktan Kec. Cianjur, Gapoktan Kec. Warungkondang, Gapoktan Kec. Geprok dan Gapoktan Kec. Cibeber, wakil dari aparat desa dan kecamatan, Wakil Komisi III DPRD Kab, Cianjur, Disperindag Kab. Cianjur, Bagian Hukum Sekda Kab. Cianjur, Kepala Dinas Pertanian Tanaman pangan dan Holtikultura dan jajarannya, serta Wakil Bupati Kab. Cianjur. Keseluruhan peserta berjumlah 26 orang. Hadirnya komponen-komponen beras Pandan Wangi Cianjur ini menggambarkan bahwa kesadaran, keinginan dan tanggung jawab atas keberadaan beras Pandan Wangi Cianjur sebagai asset daerah berlangsung melalui inisiatif dari bawah (bottom-up) dan dari atas (top-bottom). Bapak Wakil Bupati Kabupaten Cianjur, Bapak Dr. Dadang Sufianto, Drs, MM. menyampaikan harapannya agar Unisba dapat membantu berkontribusi terhadap terciptanya perlindungan hukum Beras Pandan Wangi Cianjur.

Hasil kegiatan penyuluhan tentang perlindungan hukum Indikasi Geografis bagi beras Pandan Wangi Cianjur yang telah dilakukan adalah sebagai berikut:

a. penentuan khalayak sasaran strategis penyuluhan yakni petani beras Pandan Wangi Cianjur dan aparat pemerintahan Kab. Cianjur. Alasan petani sebagai sasaran strategis karena petani beras di Kabupaten Cianjur, sebagai sampelnya adalah kelompok tani Kec. Warungkondang, Kec. Cugenang, Kec. Cibeber, Kec. Cianjur, dan Kec. Cilaku (sekarang Kec. Gebrok) belum mendapatkan perlindungan hukum Indikasi Geografis. Pertimbangan akan khalayak sasaran yang ditetapkan diatas yaitu aparat pemerintah Kab. Cianjur berdasarkan alasan bahwa Indikasi Geografis, yang kepemilikannya harus melalui pendaftaran dan perizinan dari negara, maka kahalayak sasaran adalah mereka yang mempunyai alas hak untuk melakukan pendaftaran.

b. dilakukannya penunjukan secara langsung berdasarkan musyawarah bahwa Pemkab. Cianjur lah yang akan menjadi lembaga pemohon pendaftaran mewakili seluruh elemen masyarakat Kab. Cianjur. Pemkab. Cianjur yang diwakili oleh Wakil Bupati Kab. Cianjur langsung mendelegasikan kepada pihak-pihak terkait pengisian Buku Persyaratan sebagai prasarat mutlak pendaftaran untuk mempersiapkan segala hal terkait pengurusan administratif berdasarkan tugas kerjanya masing-masing.

c. sebagai tindakan awal, pemetaan hak Indikasi Geografis beras Pandan Wangi Cianjur berdasarkan pada Keputusan Menteri Pertanian Nomor: 163/Kpts/LB.240/3/2004 Tanggal: 17 Maret 2004 tentang Pelepasan Galur Padi Sawah Lokal Pandan Wangi Cianjur Sebagai Varietas Unggul Dengan Nama Pandan Wangi

\section{Deskripsi Padi Sawah Varietas Pandan Wangi:} Cianjur

Asal: Populasi varietas lokal Pandan Wangi

Nomor Aksesi koleksi $\quad$ : Balitpa 1644

Metode Seleksi : Galur murni

Golongan : Berbulu

Umur tanaman $\quad: 155$ hari

Bentuk tanaman : : Kompak

Tinggi tanaman $\quad: 168 \mathrm{~cm}$

Anakan produktif $\quad: 15-18$ batang

Warna kaki : Hijau

Warna batang : Hijau

Warna telinga daun : Tidak berwarna

Warna lidah daun : Tidak berwarna

Warna helai daun : Hijau

Muka daun : Kasar

Posisi daun : : Tegak

Daun bendera : : : Tegak

Bentuk gabah : Bulat

Warna gabah : Kuning mas

Kerontokan : Tahan 
Kerebahan

Tekstur nasi

Bobot 1000 butir

Kadar amilosa

Potensi hasil

Rata-rata hasil

: Kurang tahan
: Pulen
$: 29,7$ gram
$: 24,96 \%$
$: 7,4$ ton $\mathrm{GKG} / \mathrm{Ha}$
$: 5,7$ ton $\mathrm{GKG} / \mathrm{Ha}$

Ketahanan terhadap hama dan penyakit: Rentan terhadap hama wereng coklat biotipe 2 dan 3 , rentan terhadap penyakit hawar daun bakteri strain 4 , rentan terhadap penyakit tungro.

Keterangan: Baik ditanam di Kabupaten Cianjur. Peneliti Pemulia:1. Dr. Aan A. Daradjat 2. Ir. Suwito MS. Tim Peneliti: Aan A. Daradjat, Suwito, Mariani P, Hamzah B, Mamat R, Supardi, Hardedi, M. Jumadi, Tuteng Dj, Tansyah A, Iyus R, Machpudin dan H. Mansyur.

Terjadi peningkatan pengetahuan dan pemahaman masyarakat mengenai perlindungan hukum Indikasi Geografis. Angket (pre-test dan posttest) yang dibagikan kepada khalayak sasaran secara terbatas (26 eksemplar) yang terbagi dalam 1 (satu) sessi terbukti dapat diisi dengan cukup baik. Hal ini menunjukan tingkat pemahaman (aspek kognitif) khalayak sasaran meningkat dari belum memahami tata caranya menjadi memahami (lihat evaluasi kegiatan).

Dengan berhasilnya penyuluhan tentang perlindungan hukum Indikasi Geografis bagi beras Pandan Wangi Cianjur, membuka jalan untuk dilakukannya kegiatan pengabdian kepada masya-rakat tahap selanjutnya berupa peningkatan kete-rampilan sekaligus pendampingan atau advokasi untuk terwujudnya perlindungan Indikasi Geografis nama wilayah "Cianjur" dengan pendekatan dan metode yang lebih baik sehingga hasilnya lebih optimal.

Meskipun PKM ini sudah berlangsung dengan lancar karena didukung secara penuh oleh pihakpihak yang menjadi sasaran penyuluhan di Kabupaten Cianjur, namun tidak dapat dipungkiri bahwa secara sadar dirasakan dalam pengimlementasiannya akan menghadapi beberapa tantangan.

Tawaran perlindungan hukum Indikasi geografis kepada stakeholders beras Pandan Wangi "Cianjur" yang dinitroduksikan melalui kegiatan PKM ini berpotensi membawa kebingungan dan pergulatan, khususnya bagi aparat pemerintah, petani maupun masyarakat terkait untuk bisa mengintegrasikannya ke dalam kerangka normative mereka, karena meskipun ditegaskan bahwa pembangunan ekonomi yang berbasis dan berkultur HKI adalah suatu hal yang selayaknya dapat dilakukan apabila daerah ingin memenangkan persaingan dan meningkatkan kesejahteraan warganya, norma hukum ini masih terasa asing.

Peraturan-peraturan terkait HKI dimana di dalamnya tercakup perlindungan untuk Indikasi Geografis merupakan salah satu sarana untuk rekayasa sosial yang ingin merubah paradigma bahwa kekayaan sekarang selain berasal dari kepemilikan atas benda- benda berwujud ternyata juga dapat berasal dari kreatifitas, keunggulan maupun invensi (benda-benda tidak berwujud).

HKI adalah asset atau harta yang berasal dari berupa benda yang masuk kategori benda tidak berwujud (intangible assets), kepemilikan atas hak tersebut sifatnya abstrak. Kenyataannya masyarakat asli Indonesia pada umumnya tidak mengenal konsep-konsep yang bersifat abstrak sebagaimana konsep tentang HKI. Kemudian terkait konsep HKI lain yang dominan, yaitu substansinya berupa monopoli atau lebih dikenal dengan istilah Hak Eksklusif dari pemegang "hak" juga berseberangan dengan sifat masyarakat asli Indonesia. Masyarakat Indonesia tidak pernah menganggapnya sebagai kekayaan dalam arti property yang dapat dimiliki secara individual. Posisi HKI sebagai rezim individualistik dan monopolistik, dianggap bertolak belakang dengan karakter masyarakat Indonesia yang bersifat komunal dan menghargai kehidupan harmonis dengan sesama. Hal inilah yang kemudian menimbulkan disharmoni dalam penerimaan dengan tindakan nyata.

Masyarakat lokal tidak atau belum memposisikan pengetahuan tradisionalnya sebagai salah satu bentuk kekayaan intelektual apalagi menjadi suatu sumber manfaat ekonomi. Faktor budaya masyarakat yang bersifat komunal menyebabkan mereka sulit untuk menerima konsep-konsep HKI yang menonjolkan hakhak pribadi. Artinya melindungi HKI sama dengan mengingkari prinsip hidup bersama dalam suasana gotong-royong, dimana kepemilikan komunal lebih dikedepankan daripada kepemilikan pribadi.

\section{Perlindungan Indikasi Geografis menurut Perundang-Undangan Indonesia}

Indikasi Geografis diatur dalam Undang-Undang Nomor 15 Tahun 2001 tentang Merek. (Lihat Undangundang Nomor 15 Tahun 2001) Dalam pengaturan UU Merek, Indikasi Geografis dilindungi sebagai suatu tanda yang menunjukkan daerah asal suatu barang, yang karena faktor lingkungan geografis termasuk faktor alam, faktor manusia, atau kombinasi dari kedua faktor tersebut, memberikan ciri dan kualitas tertentu pada barang yang dihasilkan. (lihat Pasal 56 ayat 1).

Seperti yang termuat dalam penjelasan Pasal 56 ayat (1) Undang-Undang Merek, perlindungan Indikasi Geografis meliputi barang-barang yang dihasilkan oleh alam, barang hasil pertanian, hasil kerajinan tangan; atau hasil industri tertentu lainnya. Artinya, Obyek indikasi geografis tidak dibatasi secara tegas hanya berupa hasil alam, akan tetapi dapat mencakup hasil budaya.

Ada beberapa pasal dalam UU Merek yang mengatur tentang Indikasi geografis. Dalam Pasal 56 UU Merek dinyatakan bahwa:

(1) Indikasi Geografis dilindungi sebagai suatu tanda yang menunjukkan daerah asal suatu barang, yang karena faktor lingkungan geografis termasuk faktor alam, faktor manusia, atau kombinasi dari kedua faktor tersebut, memberikan ciri dan kualitas tertentu pada barang yang dihasilkan.

(2) Indikasi Geografis mendapat perlindungan setelah terdaftar atas dasar permohonan yang diajukan oleh:

a. lembaga yang mewakili masyarakat di daerah yang memproduksi barang yang bersangkutan, yang terdiri atas:

1. pihak yang mengusahakan barang yang merupakan hasil alam atau kekayaan alam;

2. produsen barang hasil pertanian; 
3. pembuat barang-barang kerajinan tangan atau hasil industri; atau

4. pedagang yang menjual barang tersebut;

b. lembaga yang diberi kewenangan untuk itu; atau c. kelompok konsumen barang tersebut.

(3) Ketentuan mengenai pengumuman sebagaimana dimaksud dalam Pasal 21, Pasal 22, Pasal 23, Pasal 24, dan Pasal 25 berlaku secara mutatis mutandis bagi pengumuman permohonan pendaftaran Indikasi Geografis.

(4) Permohonan pendaftaran Indikasi Geografis ditolak oleh Direktorat Jenderal apabila tanda tersebut:

a. bertentangan dengan moralitas agama, kesusilaan, ketertiban umum, atau dapat memperdayakan atau menyesatkan masyarakat mengenai sifat, ciri, kualitas, asal sumber, proses pembuatan, dan/atau kegunaannya;

b. tidak memenuhi syarat untuk didaftar sebagai Indikasi Geografis.

(5) Terhadap penolakan sebagaimana dimaksud pada ayat (4) dapat dimintakan banding kepada Komisi Banding Merek.

(6) Ketentuan mengenai banding dalam Pasal 29, Pasal 30, Pasal 31, Pasal 32, Pasal 33, dan Pasal 34 berlaku secara mutatis mutandis bagi permintaan banding sebagaimana dimaksud pada ayat (5).

(7) Indikasi Geografis terdaftar mendapat perlindungan hukum yang berlangsung selama ciri dan/atau kualitas yang menjadi dasar bagi diberikannya perlindungan atas Indikasi Geografis tersebut masih ada.

(8) Apabila sebelum atau pada saat dimohonkan pendaftaran sebagai Indikasi Geografis, suatu tanda telah dipakaidengan iktikad baik oleh pihak lain yang tidak berhak mendaftar menurut ketentuan sebagaimana dimaksudpada ayat (2), pihak yang beriktikad baik tersebut tetap dapat menggunakan tanda tersebut untuk jangka waktu2 (dua) tahun terhitung sejak tanda tersebut terdaftar sebagai Indikasi Geografis.

(9) Ketentuan mengenai tata cara pendaftaran Indikasi Geografis diatur lebih lanjut dengan Peraturan Pemerintah.

Pasal 56 UU Merek di atas menyiratkan bahwa perlindungan Merek, berlaku juga bagi Indikasi Geografis. Miranda menyatakan bahwa dalam UU Merek tersebut terkandung kaidah "penunjuk", (Ayu, 2006). Diantaranya dalam Pasal 56 ayat (3) ditentukan bahwa Pasal 21, Pasal 22, Pasal 23, Pasal 24, dan Pasal 25 yang mengatur pengumuman permohonan pendaftaran merek, berlaku secara mutatis mutandis bagi permohonan pendaftaran Indikasi Geografis.

Pasal lainnya yang mengatur tentang Indikasi Geografis adalah Pasal 57 UU Merek yang menyatakan bahwa Pemegang hak atas Indikasi Geografis dapat mengajukan gugatan terhadap pemakai Indikasi Geografis yang tanpa hak berupa permohonan ganti rugi dan penghentian penggunaan serta pemusnahan etiket Indikasi Geografis yang digunakan secara tanpa hak tersebut. Untuk mencegah kerugian yang lebih besar pada pihak yang haknya dilanggar, hakim dapat memerintahkan pelanggar untuk menghentikan kegiatan pembuatan, perbanyakan, serta memerintahkan pemusnahan etiket Indikasi Geografis yang digunakan secara tanpa hak tersebut.

Menurut Pasal 1 angka 1 Peraturan Pemerintah Nomor 51 Tahun 2007 tentang Indikasi Geografis, Indikasi Geografis adalah suatu tanda yang menunjukkan daerah asal suatu barang, yang karena faktor lingkungan geografis termasuk faktor alam, faktor manusia, atau kombinasi dari kedua faktor tersebut, memberikan ciri dan kualitas tertentu pada barang yang dihasilkan.

Jadi Indikasi Geografis adalah suatu indikasi atau identitas dari suatu barang yang berasal dari suatu tempat, daerah atau wilayah tertentu yang menunjukan adanya kualitas, reputasi dan karakteristik termasuk faktor alam dan manusia yang dijadikan atribut dari barang tersebut.

Indikasi Geografis melindungi "nama wilayah" untuk digunakan sebagai tanda pada produk-produk yang diindikasikan sebagai produk Indikasi Geografis. Indikasi Geografis merupakan suatu tanda yang tanpa disadari sudah lama ada dan secara tidak langsung dapat menunjukkan adanya kekhususan pada suatu barang yang dihasilkan dari daerah tertentu. (Penjelasan Umum alenia 3 Peraturan Pemerintah Nomor 51 Tahun 2007 Tanda dimaksud selanjutnya dapat digunakan untuk menunjukkan nama tempat asal suatu barang, baik yang berupa hasil pertanian, bahan pangan, hasil kerajinan tangan, atau barang lainnya, termasuk bahan mentah dan/ atau hasil olahan, baik yang berasal dari hasil pertanian maupun yang berasal dari hasil tambang. (Pasal 2 ayat 1-2 Peraturan Pemerintah Nomor 51 Tahun 2007) Contoh produk Indikasi Geografis di Indonesia adalah Kopi Toraja, Kopi Kintamani, Ubi Cilembu, Beras Delanggu, Mangga Indramayu, Peuyeum Bandung, Tahu Sumedang, Beras Cianjur. Penunjukkan asal suatu barang merupakan hal penting, karena pengaruh dari faktor geografis termasuk faktor alam, faktor manusia, atau kombinasi dari kedua faktor tersebut di daerah/ desa tempat barang tersebut dihasilkan dapat memberikan ciri dan kualitas tertentu pada barang tersebut. Ciri dan kualitas barang yang dipelihara dan dapat dipertahankan dalam jangka waktu tertentu akan melahirkan reputasi (keterkenalan) atas barang tersebut, yang selanjutnya memungkinkan barang tersebut memiliki nilai ekonomi tinggi. Karena itu sepatutnya barang tersebut mendapat perlindungan hukum yang memadai.

Sebagaimana terdapat dalam Pasal 2 ayat ((3) Peraturan Pemerintah Nomor 51 Tahun 2007 tentang Indikasi Geografis, tanda berupa "nama wilayah" dapat dilindungi sebagai Indikasi Geografis apabila telah terdaftar dalam Daftar Umum Indikasi Geografis, yaitu suatu buku yang memuat Indikasi Geografis yang terdaftar pada Direktorat Jenderal Hak Kekayaan Intelektual. Artinya, perlindungan hukum Indikasi Geografis yang melekat setelah pendaftaran oleh pihak Pemohon akan berlangsung selama ciri khas masih ada dan/atau kualitasnya dijaga secara terus menerus. Untuk mengetahui masih ada atau tidaknya ciri khas dan kualitas pada suatu produk Indikasi Geografis, PP 
mensyaratkan pengisian Buku Persyaratan oleh Pihak Pemohon pendaftar produk Indikasi Geografis.

Buku Persyaratan seperti yang tercantum dalam Pasal 1 angka 9 Peraturan Pemerintah Nomor 51 Tahun 2007 tentang Indikasi Geografis adalah suatu dokumen yang memuat informasi tentang kualitas dan karakteristik yang khas dari barang yang dapat digunakan untuk membedakan barang yang satu dengan barang lainnya yang memiliki kategori sama. Buku Persyaratan ini berfungsi sebagai pedoman tentang ciri khas/ karakteristik dan kualitas barang.

Tidak semua hasil alam, kerajinan, maupun kombinasi dari keduanya dapat didaftarkan sebagai Indikasi Geografis. Ada kemungkinan permohonan pendaftaran Indikasi Geografis ditolak oleh Tim Ahli Indikasi Geografis, yang berada di bawah Sub Direktorat Indikasi Geografis, Direktorat Merek, Direktorat Jenderal Hak Kekayaan Intelektual, Departemen Hukum dan HAM. Dalam Pasal 3 Peraturan Pemerintah Nomor 51 Tahun 2007 tentang Indikasi Geografis dinyatakan:

"Indikasi Geografis tidak dapat didaftar apabila tanda yang dimohonkan pendaftarannya :

a. bertentangan dengan peraturan perundangundangan, moralitas agama, kesusilaan atau ketertiban umum;

b. menyesatkan atau memperdaya masyarakat mengenai: ciri, sifat, kualitas, asal sumber, proses pembuatan barang, dan/atau kegunaannya;

c. merupakan nama geografis setempat yang telah digunakan sebagai nama varietas tanaman, dan digunakan bagi varietas tanaman yang sejenis; atau

d. telah menjadi generik."

\section{E. Implikasi Perlindungan Hukum Indikasi- geografis terhadap Peningkatan Pertumbuhan Ekonomi Masyarakat}

Menurut Miranda, Indikasi Geografis amat menghargai keterkaitan historis dari suatu produk dengan tempat asalnya. Indikasi Geografis potensial untuk difungsikan sebagai "perekat" produk kepada daerah asal, sehingga produk yang dilindunginya dapat tetap memberi keuntungan ekonomis tertinggi bagi produsen asli dari daerah asal produk tersebut. Miranda Risang Ayu, Op. Cit., hlm. 151.

Sebagai cara untuk menyeimbangkan kepentingan antara peranan pribadi individu dengan kepentingan masyarakat, maka sistem HKI termasuk di dalamnya Indikasi Geografis berdasarkan pada prinsip keadilan, prinsip ekonomi, prinsip kebudayaan, dan prinsip sosial. Afrillyanna Purba, 2005). Sebagai bagian dari HKI, Indikasi-geografis melindungi kepentingan masyarakat/ komunal.

Menurut Frederick Abbott, et.al., isu Indikasigeografis memiliki dua fungsi. Pertama, fungsi promosi produk yang mempunyai karakter tertentu yang membawa manfaat ke wilayah tempat produk tersebut dibuat (manufactured) atau dipasarkan. Indikasi-geografis dengan demikian melindungi produsen di wilayah tersebut terhadap penggunaan yang tidak sah (anauthorized) dari goodwill yang diciptakan oleh kualitas produk itu oleh pesaingnya. Kedua, Indikasi-geografis adalah sumber informasi penting untuk konsumen pada pasar yang sangat beragam dalam kaitan dengan asal, kualitas serta reputasi produk yang bersangkutan. (Achmad Zen Umar Purba, 2002).

Suatu perlindungan hukum Indikasi-geografis oleh suatu kelompok masyarakat, bukan berarti menutup kesempatan bagi pihak lain untuk menggunakan "nama wilayah" yang bersangkutan pada produk yang dapat diindikasikan sebagai produk Indikasi-geografis. Pihak ketiga siapapun tetap dapat mencantumkan "nama wilayah" pada merek dagangnya, sepanjang keaslian produk barang tetap dapat dijamin sesuai dengan keluarannya. ( Tatty A. Ramli dan Yeti Sumiyati, 2008) Tentu saja pencantuman "nama wilayah" pada merek dagang melalui kebijakan mekanisme lisensi atau ijin penggunaan dengan membayar sejumlah uang sebagai bentuk royalty kepada pemegang hak. Pemegang hak atas Indikasi-geografis dapat mengajukan gugatan terhadap pemakai Indikasi-geografi tanpa hak berupa permohonan ganti rugi dan penghentian penggunaan serta pemusnahan etiket Indikasi-geografis yang digunakan secara tanpa hak tersebut.

Dengan demikian, melalui perlindungan Indikasi-geografis, hanya produk asli yang dihasilkan dari daerah itu saja yang berhak mencantumkan "nama wilayah" pada merek dagangnya.

Beras Basmati asal India adalah contoh produk Indikasi-geografis berupa "tanda" menunjukan "nama wilayah" yang telah terdaftar, dilindungi oleh negara dari penggunaan oleh pihak ke-3 secara tanpa hak. India telah bertahun-tahun dikenal sebagai produsen beras beraroma dan berbutir panjang dari varietas lokal suatu daerah yang disebut "Basmati". Basmati telah digunakan dan diterima di seluruh dunia sebagai jenis beras yang tumbuh dan dihasilkan di Basmati. Bertahuntahun beras Basmati telah menjadi komoditas ekspor yang mendatangkan devisa bagi India. Permasalahan muncul ketika Ricetec perusahaan asal Amerika menggunakan kata Texmati dan/atau Kasmati untuk strain beras yang telah dikembangkan dari varietas lokal Basmati. Berdasarkan Pasal 22 TRIP's, penggunaan oleh anggota dengan cara apapun tanda atau tampilan barang berasal dari suatu wilayah geografis yang bukan benar-benar tempat asal, yang dapat mengelabui publik sebagai daerah asal adalah dilarang. Dengan adanya ketentuan tersebut, Basmati dapat dikategorikan merupakan arti suatu nama geografis. Kata Basmati telah diasosiasikan oleh konsumen di seluruh dunia sebagai beras beraroma dan berbutir panjang dengan rasa tertentu yang aslinya tumbuh di wilayah Basmati, India. Kepedulian konsumen terhadap kata Basmati dan asosiasi mereka atas kata Basmati terhadap beras berkualitas telah dengan jelas mendorong Ricetec untuk memperoleh reputasi (goodwill) Basmati dengan menjual beras hasil pengembangan varietas asli Basmati dengan nama Texmati dan/atau Kasmati. Penggunaan nama merek semacam ini dapat dengan mudah menyebabkan konsumen berasosiasi bahwa berasnya adalah tipe beras yang benar-benar tumbuh di Basmati, India. Jika saja "Basmati" ditemukan sebagai varietas generik beras, dan tidak sebagai nama geografis, maka India dapat kehilangan pasar ekspor yang ada dari beras Basmati mereka terhadap entitas bisnis lainnya yang menghasilkan varietas sejenis dari suatu tempat. 
Perlawanan India dalam masalah ini membuktikan bahwa Basmati bukan varietas generik beras, tetapi mewakili nama geografis. Dan oleh karena itu, bisa menggunakan WTO untuk menghentikan pelanggaran ini.(Helianti Hilman dan Ahdian Romadoni, 2001).

\section{F. Peluang dan Tantangan Perlindungan Hukum Indikasi Geografis Beras Pandan Wangi Cianjur}

Dalam paparan materi penyuluhan, Tim PKM mendeskripsikan peluang dan tantangan untuk pelaksanaan pendaftaran Indikasi Geografis Beras Pandan Wangi Cianjur. Pentingnya penyusunan Buku Persyaratan sebagai prasarat utama pendaftaran juga dideskripsikan oleh Tim PKM.

Berdasarkan deskripsi/ uraian yang harus diisi dalam Buku Persyaratan, maka Tim PKM memberikan saran antara lain 1) masing-masing dinas terkait, termasuk Bappeda Kab. Cianjur harus menyusun Renstra terkait langkah-langkah untuk mendapatkan perlindungan hukum Indikasi Geografis bagi Beras Pandan Wangi Cianjur yang diawali dengan mendorong terbentuknya lembaga perwakilan untuk pendaftaran. Renstra ini disusun untuk diajukan pada proposal kegiatan yang dialokasikan dari APBD Kab. Cianjur. Konsolidasi perlu segera dilakukan untuk pertemuan antara pihak terkait, menentukan format lembaga, menentukan anggota peserta, menentukan susunan organisasi lembaga, mempelajari PP, dan membuat agenda kerja; 2) Lembaga yang diusulkan Tim PKM merupakan perwakilan dari komponen pihak terkait Beras Pandan Wangi Cianjur, diantaranya unit kelompok tani, unit kerja masyarakat lokal, unit kerja Bandar/ produsen, unit kerja Dinas Pertanian, unit kerja Birokrasi Pemkab Sumedang, dan unit kerja Dinas Perdagangan. Ramli dan Sumiyati, 2009.

Dari keseluruhan prosentase evaluasi pre-test dan post-test menunjukan telah terjadi peningkatan pengetahuan dan pemahaman responden terkait perlindungan hukum Indikasi Geografis bagi Beras Pandan Wangi Cianjur. Akan tetapi, peningkatan pengetahuan dan pemahaman masyarakat Kab. Cianjur terkait perlindungan hukum Indikasi Geografis belum menjamin terlaksananya pendaftaran. Hal ini seperti yang dijelaskan sebelumnya sangat tergantung dari tingkat kesadaran masyarakat yang berbanding lurus dengan faktor budaya masyarakat.

Hal tersebut menunjukan, bahwa tingkat kesadaran masyarakat, baik masyarakat penghasil produk hasil alam dan kerajinan maupun masyarakat konsumen, untuk melindungi nama wilayah sebagai tanda yang menunjukan daerah asal suatu barang masih rendah. Padahal, perlindungan hukum terhadap produk yang dapat diindikasikan sebagai produk Indikasigeografis sangat tergantung dari tingkat kesadaran masyarakat akan pentingnya perlindungan hukum ini.

Sangat tepat pendapat Lawrence M. Friedman Lawrence M. Friedman, 2001. terkait masalah pendaftaran Indikasi-geografis yang berpotensi meningkatkan pertumbuhan ekonomi masyarakat Kabupaten Cianjur. Menurut Friedman, ada tiga unsur sistem hukum (Three Elements of Legal Sistem) yaitu struktur (lembaga yang memiliki otoritas), substansi (peraturan perundang-undangan) dan kultur hukum (budaya masyarakat). Suatu peraturan dapat berlaku secara efektif memberikan perlindungan hukum bagi masyarakat apabila ketiga unsur hukum tersebut terpenuhi, karena apabila diibaratkan, struktur hukum seperti mesin, substansi adalah apa yang dihasilkan atau dikerjakan oleh mesin itu, dan budaya hukum adalah apa saja atau siapa saja yang memutuskan untuk menghidupkan dan mematikan mesin itu serta memutuskan bagaimana mesin itu digunakan.

\section{a. Peraturan Perundang-Undangan}

Pendaftaran suatu produk yang potensial dilindungi sebagai produk Indikas-geografis dalam PP Nomor 51 Tahun 2007 tentang Indikasi Geografis yang mengatur tentang tata cara pendaftaran Indikasi-geografis, dimaksudkan untuk melaksanakan secara menyeluruh ketentuan Pasal 56 ayat (9) UU Nomor 15 Tahun 2001 tentang Merek. PP yang disusun oleh Pemerintah tersebut diharapkan dapat memberikan kegunaan berupa perlindungan hukum yang mendatangkan manfaat ekonomi bagi masyarakat penghasil komoditas/ produk komoditas/ barang di seluruh wilayah Indonesia yang memiliki kualitas dan karakteristik yang khas yang dapat digunakan untuk membedakan barang yang satu dengan barang lainnya yang memiliki kategori sama.

Pihak yang dapat menjadi Pemohon pendaftaran dalam PP Indikasi Geografis adalah: Lembaga yang mewakili masyarakat di daerah yang memproduksi barang yang bersangkutan, yang terdiri atas: pihak yang mengusahakan barang yang merupakan hasil alam atau kekayaan alam; produsen barang hasil pertanian; pembuat barang-barang kerajinan tangan atau hasil industri; atau pedagang yang menjual barang tersebut. Lembaga yang diberi kewenangan untuk itu; atau Kelompok konsumen barang tersebut.

Menurut hemat penulis, menentukan pihak yang akan menjadi Pemohon ini dapat menyebabkan proses pendaftaran menjadi sulit untuk direalisasikan. Terlebih dengan adanya prasarat pengisian Buku Persyaratan oleh Pemohon, yaitu suatu dokumen yang di dalamnya memuat informasi tentang kualitas dan karakteristik yang khas dari barang yang dapat digunakan untuk membedakan barang yang satu dengan barang lainnya yang memiliki kategori sama. Adanya keharusan menguraikan hal-hal substantif dan administratif suatu Indikasi-geografis dalam Buku Persyaratan hanya dimungkinkan diisi oleh Pemohon yang memiliki kompetensi di bidangnya masing-masing. Usulan penulis kepada masyarakat terkait beras Pandan Wangi Cianjur adalah Pemerintah Daerah kabupaten Cianjur lah (yang didalamnya terdiri dari gabungan yang mewakili masyarakat petani, produsen dan konsumen) yang paling tepat mewakili masyarakat untuk menjadi pihak pemohon pendaftaran beras Pandan Wangi Cianjur ke Dirjen HKI sebagaimana hasil musyawarah dalam acara penyuluhan. Hal ini dilatarbelakangi oleh pengalaman penulis meneliti dan memberikan penyuluhan kepada masyarakat petani Ubi Cilembu dari mulai Tahun 2002-2009.

\section{b. Budaya Hukum Masyarakat}

Faktor yang menjadi penghambat dilakukannya pendaftaran sehingga potensinya belum mampu meningkatkan pertumbuhan ekonomi masyarakat Kabupaten Cianjur, terkait dengan struktur dan budaya hukum masyarakat. Dari semenjak dikeluarkannya 
PP tentang Indikasi-geografis Tahun 2007, hanya ada beberapa produk Indikasi Geografis salah satunya yaitu Kopi Arabika Kintamani Bali yang didaftarkan ke Dirjen HKI. Itu pun karena pendaftaran Kopi Arabika Kintamani Bali merupakan pilot projek dari pemerintah Perancis.

Hal tersebut menunjukan, bahwa tingkat kesadaran masyarakat, baik masyarakat penghasil produk hasil alam dan kerajinan maupun masyarakat konsumen, untuk melindungi nama wilayah sebagai tanda yang menunjukan daerah asal suatu barang masih rendah. Padahal, perlindungan hukum terhadap produk yang dapat diindikasikan sebagai produk Indikasi-geografis sangat tergantung dari tingkat kesadaran masyarakat akan pentingnya perlindungan hukum ini. Seperti yang diungkapkan Friedman, kesadaran masyarakat yang menentukan akan dilindungi atau tidaknya tanda yang menunjukan nama wilayah penghasil produk yang memiliki ciri dan kualitas barang karena faktor geografis termasuk faktor alam, faktor manusia atau kombinasi keduanya. Masyarakat yang menentukan apakah ciri dan kualitas barang tersebut akan dipelihara dan dipertahankan dalam jangka waktu tertentu sehingga melahirkan reputasi (keterkenalan) atas barang tersebut, yang selanjutnya memungkinkan barang tersebut memiliki nilai ekonomi tinggi. Masyarakat pula lah sebagai Pemohon pendaftar Indikasi-geografis seperti tertuang dalam Pasal 5 ayat (3) PP Nomor 51 Tahun 2007 tentang Indikasi Geografis, yang menentukan apakah tanda yang menunjukan nama wilayah penghasil produk Indikasi-geografis yang dihasilkan di wilayah mereka, harus didaftarkan atau tidak. Jadi, potensi Indikasigeografis dalam meningkatkan pertumbuhan ekonomi masyarakat sangat tergantung dari kesadaran masyarakat untuk melindungi tanda yang menunjukan nama wilayah penghasil produk Indikasi-geografis yang dihasilkan di wilayah mereka melalui pendaftaran ke Dirjen HKI.

\section{c. Struktur Hukum}

Dengan berbagai potensi Indikasi-geografis dalam meningkatkan pertumbuhan ekonomi masyarakat, sudah seyogyanya pemerintah memberikan perlindungan, dengan maksud menyediakan cara untuk menghindari penggunaan Indikasi-geografis dengan cara apapun, dalam memberi tanda atau menampilkan barang yang dapat mengindikasikan atau mencitrakan bahwa barang yang diperdagangkan berasal dari suatu wilayah geografis yang bukan dari tempat asal yang sebenarnya. Bentuk perlindungan dari pemerintah bagi kepentingan masyarakat dapat dilakukan dengan mendukung usaha masyarakat kearah pendaftaran berupa misalnya melakukan pemetaan terhadap produk Indikasi-geografis di daerahnya, menyediakan fasilitas untuk melengkapi persyaratan-persyaratan teknis administratif untuk pendaftaran produk Indikasi-geografis, dan sebagai mediator terbentuknya Pemohon pendaftar.

Menyikapi kendala-kendala dan resistensi sebagaimana telah diuraikan di atas, Tim PKM UNISBA bersikukuh untuk terus mengedukasi masyarakat tentang perlunya perlindungan HKI, khususnya Indikasi Geografis. Diyakini bahwa dari seluruh rezim HKI yaitu Paten, Merek, Hak Cipta, Rahasia Dagang, Desain Industri dan Tata Letak Sirkuit Terpadu, maka rezim Merek yang di dalamnya tercakup perlindungan Indikasi
Geografis merupakan rezim yang paling besar peluangnya untuk diimplementasikan oleh Indonesia sebagai Negara berkembang yang berbasis agraria.

\section{SIMPULAN}

Dari hasil evaluasi pre-test dan post-test penyuluhan tentang perlindungan hukum Indikasi Geografis bagi beras Pandan Wangi Cianjur dapat disimpulkan bahwa:

1. masyarakat Petani dan Jajaran Pemkab. Cianjur mulai mengetahui bahwa Beras Pandan Wangi Cianjur dapat dilindungi secara hukum melalui rezim HKI khususnya perlindungan Indikasi Geografis yang diatur dalam Peraturan Pemerintah Nomor 51 Tahun 2007 tentang Indikasi Geografis.

2. pemangku kepentingan beras Pandan Wangi Cianjur memahami bahwa perlindungan HKI baru eksis apabila telah ada pengakuan dari pemerintah sehingga perlu dilakukan pendaftaran segera karena sistem pendaftaran menganut sistem first to file.

3. pemangku kepentingan beras Pandan Wangi Cianjur akan segera berkoordinasi untuk menetapkan perwakilan yang akan bertindak sebagai pemohon dan melakukan pembagian tugas dalam rangka penyusunan Buku Persyaratan.

\section{DAFTAR PUSTAKA}

Abdulkadir Muhammad, Kajian Hukum Ekonomi Hak Kekayaan Intelektual, Citra Aditya Bakti, Bandung, 2001.

Andy Noorsaman Sommeng dan Agung Damar Sasongko, Indikasi Geografis: Sebuah Pengantar, Direktorat Jenderal HKI (DJHKI), Jakarta, 2008.

Afrillyanna Purba, at. al, TRIP's - WTO \& Hukum HKI Indonesia: Kajian Perlindungan Hak Cipta Seni Batik Tradisional Indonesia, Rineka Cipta, Jakarta, 2005.

Achmad Zen Umar Purba, Hak Kekayaan Intelektual Pasca TRIPs, Cet. Pertama, Alumni, Bandung, 2002.

Beras Pandan Wangi Oplosan beredar di Cianjur, http://www.indosiar.com/fokus/59964/beraspandan-wangi-oplosan-beredar-di-cianjur, 24 Maret 2007.

Emawati Junus, Pentingnya Perlindungan Indikasi Geografis sebagai Bagian dari HKI dan Pelaksanaannya di Indonesia, Makalah pada Seminar Nasional "Perlindungan Indikasi Geografis di Indonesia, Jakarta, 6-7 Desember 2004 .

Eddy Damian, Arti HKI dan Potensinya sebagai Sumber Ekonomi Jawa Barat, Makalah pada Seminar Sehari "Pemberdayaan Hak atas Kekayaan Intelektual sebagai Pilar Pembangunan Perekonomian Jawa Barat," Bandung, 31 Mei 2004. 
Helianti Hilman dan Ahdian Romadoni, Pengelolaan dan Perlindungan Aset Kekayaan Intelektual, The British Council-DFID-ITB, Jakarta, 2001.

Keputusan Menteri Pertanian Nomor 163/Kpts/ LB.240/ 3/ 2004 tentang Pelepasan Galur Padi Sawah Lokal Pandan Wangi Cianjur sebagai Varietas Unggul dengan Nama Pandan Wangi.

Lawrence M. Friedman, American Law an Introduction, Hukum Amerika: Sebuah Pengantar, Penerjemah: Wishnu Basuki, Tatanusa, Jakarta, 2001.

Miranda Risang Ayu, Mamperbincangkan Hak Kekayaan Intelektual Indikasi Geografis, Alumni, Bandung, 2006.

Sudargo Gautama dan Rizawanto Winata, Undangundang Merek Baru Tahun 2001, Citra Aditya Bakti, Bandung, 2002.

Suyud Margono dan Amir Angkasa, Komersialisasi Aset Intelektual: Aspek Hukum Bisnis, Grasindo, Jakarta, 2002.
Handri Handrian, Elegi Pandan Wangi, Pikiran Rakyat, Rabu, 10 Juni 2009.

Sunaryati Hartono dan Eli Ermawati, Hukum Ekonomi, Diktat Kuliah, Universitas Parahyangan, tanpa tahun.

Tatty A. Ramli dan Yeti Sumiyati, Diseminasi Model Integrasi Lembaga Perwakilan untuk Pendaftaran sebagai Alternatif Pendaftaran untuk Memperoleh Perlindungan Hukum Indikasi Geografis Beras Pandan Wangi Cianjur, Laporan Hasil Penelitian Hibah Bersaing Lanjutan yang dibiayai oleh Direktorat Jenderal Pendidikan Tinggi, Departemen Pendidikan Nasional, Sesuai dengan Surat Perjanjian Pelaksanaan Hibah Penelitian Nomor: 040/ SP2H/PP/DP2M/IV/2009, Maret 2009.

Yeti Sumiyati, Masih Ada Harapan Bagi pandan Wangi, Pirkiran Rakyat, 17 Juni 2009.

UU No. 15 tahun 2001 tentang Merek

PP Nomor 51 Tahun 2007 Indikasi Geografis 